\title{
Recovery of Valuable Components from Food Wastes by Microwave Assisted Extraction
}

\author{
Derya Kocak Yanik (Corresponding author) \\ Food Engineering Department, Engineering Faculty, \\ Gaziantep University, 27310, Gaziantep, Turkey \\ E-mail: dkocak@gantep.edu.tr \\ Hatice Neval Ozbek \\ Food Engineering Department, Engineering Faculty, \\ Gaziantep University, 27310, Gaziantep, Turkey \\ E-mail: haticeneval@gantep.edu.tr \\ Fahrettin Gogus \\ Food Engineering Department, Engineering Faculty, \\ Gaziantep University, 27310, Gaziantep, Turkey \\ E-mail: fahret@gantep.edu.tr
}

\begin{abstract}
Today, insufficiency of natural resources, rapidly growing world population, climate change, food losses and food waste cause significant risk for food safety. In food industries, high amounts of solid and liquid wastes are released at various stages of production. The majority of them are organic wastes left from the raw material processed. Food waste, food and nutrition safety and food quality affect the sustainability and economic development of food systems and have negative impacts on natural resources and environmental protection. In addition, these food wastes can be converted into useful products which have market value, such as polyphenols, dietary fiber and photochemistry etc. Therefore, studies on the assessment of these wastes are becoming increasingly important and quick and effective new applications are needed.

Traditional extraction methods usually take a long time and require large amounts of solvent. Microwave-assisted solvent extraction (MASE) is one of the modern methods which have been used more commonly in recent years, with short extraction time, less solvent usage and lower energy requirements, higher heating rates, higher extraction efficiency, higher selectivity and better quality target products. Microwave-assisted solvent extraction is one of the modern methods with its increasing use in recent years. In this study, microwave extraction has been studied in general and the studies on the extraction of valuable components by microwave extraction technique from food wastes were compiled.
\end{abstract}

Keywords: Food waste, Microwave assisted extraction

DOI: $10.7176 /$ JSTR/6-09-05

\section{Gida Atıklarından Mikrodalga Destekli Ekstraksiyon Yöntemiyle Değerli Bileșenlerin Geri Kazanımı}

Özet

Günümüzde doğal kaynakların yetersizliği, hızla artan dünya nüfusu, iklim değişiklikleri, gıda kayıpları ve gıda atıkları gıda güvenliği açısından büyük risk oluşturmaktadır. Gıda endüstrisinde üretimin çeşitli aşamalarında oldukça yüksek miktarlarda katı ve sıvı atıklar açığa çıkmaktadır. Bu atıkların büyük bölümünü işlenen hammaddeden arda kalan organik atıklar oluşturmaktadır. Gıda atıkları, gıda ve beslenme güvenliği, gıda kalitesi, gıda sistemlerinin sürdürülebilirliği ve ekonomik gelişimi, doğal kaynaklar ve çevre koruma üzerinde olumsuz etkilere sahiptir. Ayrıca bu gıda atıkları hali hazırda market değeri taşıyan faydalı ürünlere dönüştürülebilecek polifenoller, diyet lifi ve fotokimyasallar vb. 
önemli bileşenler içermektedirler. Dolayısıyla bu atıkların değerlendirilmesi yönündeki çalışmalar giderek önem kazanmakta ve hızlı ve etkili yeni uygulamalara gereksinim duyulmaktadır.

Geleneksel ekstraksiyon metotları genellikle uzun zaman almakta ve çok miktarlarda çözücü kullanımı gerektirmektedir. Mikrodalga destekli çözgen ekstraksiyonu (MDÇE) kısa ekstraksiyon süresi, daha az solvent kullanımı ve düşük enerji gereksinimi, yüksek ısıtma oranları, yüksek ekstraksiyon verimi, daha yüksek seçicilik ve daha iyi kalitede hedef ürünlerin eldesi ile avantaj sağlayan, son yıllarda kullanımı gittikçe artan modern yöntemlerden birisidir. Bu çalışmada mikrodalga ekstraksiyonu genel olarak ele alınmış olup gıda atıklarından mikrodalga ekstraksiyonu tekniğiyle değerli bileşenlerin eldesine yönelik çalışmalar derlenmiştir.

Anahtar Kelimeler: Gıda atıkları, Mikrodalga destekli ekstrasiyon

\section{Giriş}

Son yıllarda artan çevre problemleri, doğal kaynakların bilinçsizce tüketilmesi ve bunlara bağlı olarak giderek artan dünya nüfusunu beslemede sınırlı kalan gıda kaynakları oldukça önem kazanmıştır. Özellikle gittikçe artan gıda ihtiyacı ve sürdürülebilir gıda kaynakları gelecek dönemlerin başlıca problemleri arasında gösterilmektedir. Gıda atıklarının azaltılması ve/veya etkili yöntemlerle başka değerli ürünlere dönüştürülmesi bu problemlerin çözümünde önem arz etmektedir. Gıda tedarik zincirinde gıdalar yetiştirilmesi, işlenmesi, dağıtımı ve tüketimine kadar geçen süreçte çeşitli nedenlerle kaybedilmektedir. Birleşmiş Milletler Gıda ve Tarım Örgütü (FAO) 2011 raporuna göre gittikçe artan bir trend izlemekle beraber tüm dünyada üretilen gıdaların yaklaşık yılda 1.3 milyar tona karşıllk gelen üçte biri atık olarak israf edilmektedir (FAO, 2011). Gıda atıkları sadece gıda güvenliğini değil çevre ve ekonomiye de ciddi zararlar vermektedir. Bu nedenle gıda atıkları ve gıda işleme yan ürünlerinin değerlendirilmesi tüm dünyada gittikçe önem kazanmaktadır. Günümüzde, gıda atıkları değerli nutrasötikler kaynağı olarak karşımıza çıkmaktadır (Schieber ve ark., 2001; Đilas ve ark., 2009). Gıda atıklarında hali hazırda bulunan bazı değerli bileşenlerin farklı metotlarla geri kazanımı ve bunların gıda veya gıda harici (tıp, ilaç ve kozmetik vb.) alanlarda uygulama bulması bunlardan birisidir. Bu değerli bileşenlerin doğal kaynaklı materyallerden elde edilmesi de ayrıca önem arz etmektedir. $\mathrm{Bu}$ bağlamda yeni ve etkili metotlar geliştirilmiş ve hala geliştirilmektedir. Mikrodalga destekli solvent ekstraksiyonu da bu anlamda uygulama alanı gittikçe artan bir teknolojidir.

Mikrodalga destekli çözgen ekstraksiyon tekniği diğer geleneksel metodlara (sokslet, damıtma, vb.) kıyasla zamandan ciddi tasarruf sağlayan, çözgen tüketimini azaltan ve yüksek verimlilikte ürün sağlayan çevre dostu bir metottur. MDÇE'de mikrodalga 1şıması, çok hızlı bir şekilde ekstraksiyon çözgenini ve/veya örneği yüksek sıcaklıklara 1sıtmak suretiyle etkili bir ekstraksiyon sağlamaktadır.

\section{Gıda Atıklarında Bulunan Bazı Önemli Bileşenler}

Gıda endüstrisinin farklı alanlarından gelen gıda atıkları veya yan ürünleri temelde bitkisel ve hayvansal kaynaklı olmak üzere 2 grupta incelenmektedir. Hububat atıkları, kök ve yumrular, yağlı bitkiler, baklagiller, meyve ve sebze atıkları bitkisel kaynaklı atıkların altında yer alan önemli alt gruplardır. Hayvansal kaynaklı atıklar ise et işleme atıkları, balık ve deniz ürünleri atıkları ve süt ve sütçülük ürünleri atıkları olmak üzere 3 alt başlıkla sınıflandırılmaktadır (Galanakis, 2012). Bitkisel temelli atıkların çoğunluğu karbonhidrat, protein, yağ, vitamin ve biyoaktif bileşenlerce zengin atıklardır. Proteinler, mineraller, doğal pigmentler, yağ asitleri ve jelatin gibi bileşenler ise hayvansal kaynaklı atıkların önemli bileşenleridir. Aşağıda bazı bitkisel ve hayvansal kaynaklı gıda atıkları ve içerdikleri önemli bileşenler tek tek ele alınmıştır.

Gıda sanayisinin alt sektörlerinden biri olan hububat sektörü Birleşmiş Milletler Gıda ve Tarım Örgütüne (FAO) göre sektörler arasında en büyük paya sahip olanıdır ve 2019 yılında toplam tahıl üretimi 2,72 milyar ton civarındadır (FAO, 2020). Bunun bir sonucu olarak hububat sektörü aynı zamanda gıda tedarik zinciri içerisinde yüksek hacimde gıda atığı üreten sektördür. Buğday, arpa, çavdar, yulaf, pirinç vb. ürünlerinden arda kalan saman ve ayçiçek, mısır, tütün, pamuk vb. ürünlerden arda kalan sap genellikle tarlada kalan hububat yan ürünlerdir ve hayvan yemi olarak değerlendirilmektedir. Fakat tarlada kalan bu atıklar selüloz, hemiselüloz ve lignin gibi polimerlerce zengin atıklardır. Örneğin buğday samanı \%30 selüloz, \%15-25 hemiselüloz ve \%10-25 lignin içermektedir (Tamaki ve Mazza, 2010). Kepek, ruşeym (germ) ve irmik altı unu ise tahılların işlenmeleri esnasında açığa çıkan atıklardır. Hububat işletmelerinde açığa çıkan bu atıkların miktarı ve içeriği uygulanan işleme göre farklılık göstermektedir. Hububat atıkları genellikle protein, mineral ve vitamin içeriği yüksek atıklar olarak bilinmektedir. Kepek çözünür olmayan diyet lifi, lipitler, mineraller, B vitaminleri ve $\mathrm{E}$ vitaminince zengindir. Besin değeri oldukça yüksek olan ruşeym ise \%26 protein, \%17 şeker, yaklaşık \%10 kadar da $\omega-6$ ve $\omega-3$ yağ asitlerince zengin yağ içermektedir (Wang

28 | P a g e 
ve Johnson, 2001; Durante ve ark., 2012). Ruşeym aynı zamanda E vitamini, tokoferoller ve tokotrienollerin bolca bulunduğu kaynaktır (Atwell, 2001). İrmik altı unu irmik üretimi esnasında açığa çıkan bir yan üründür. Bu yan ürün kepek bakımından oldukça zengin, protein içeriği yüksek (\%14-16) ve yaklaşık \%65 nişasta içeren hafif gri renkli bir undur (Kılıç, 1999). İrmik altı unu genellikle çavdar, yulaf gibi düşük gluten içeriğine sahip hububatların gluten miktarını artırmak amacıyla katkı maddesi olarak kullanılır (Yağcı ve Gögüş, 2009). Nişasta endüstrisinde, biracılıkta ve ekmekçilikte açığa çıkan diğer atıklarda hububat sektörü atıkları gruba girmektedir. Bunlardan bira posası biracılık sektörünün temel atığıdır ve lignoselülozik bir yapıda olup polisakaritler ve polifenollerce özelliklede fenolik asitlerce zengindir (Moreira ve ark., 2012).

Baklagiller hububatlardan sonra dünyada en çok tüketilen ikinci gıda maddesidir. Birleşmiş Milletler Gıda ve Tarım Örgütünün (FAO) yayınladığı rapora göre 2014 yılında dünya genelinde toplam üretim yaklaşık 77,5 milyon ton civarındadır (FAO, 2019). Baklagil tesislerinde uygulanan temel işlemler kabuk çıkarma, puffing, öğütme ve bölme gibi işlemlerdir ve bu işlemler esnasında genellikle parçalanmış tanecikler, toz ürünler ve dış kabuk yan ürün olarak açığa çıkmaktadır. Bu yan ürünler başta protein olmak üzere, karbonhidratlar, diyet lifi, vitaminler, mineraller ve fito-kimyasallarca (polifenoller, flavonoidler, ve fitosteroller) zengindirler. $\mathrm{Bu}$ yan ürünlerin değerlendirilmesiyle ilgili çok fazla çalışma olmamasına rağmen diyet lifi üretiminde, kabukla zenginleştirilmiş baklagil unlarınının üretiminde, biyo-aktif bileşenlerin ekstraksiyonu ve baklagil proteinlerinin saflaştırılmasıyla protein konsantrelerinin üretiminde kullanıldığı bilgileri literatürde mevcuttur (Mullen ve ark., 2015)

Yenilebilir yumru ve kök bitkilerinden (patates, tatlı patates, manyok, yer elması, vb.) patates tüm dünyada bilinen ve en çok tüketilenidir. Endüstride patates farklı amaçlar için işlenebilmekte ve işlenme şekline bağlı olarak da farklı patates atıkları ortaya çıkmaktadır. Patates kabuğu, patates doğrama atıkları, patates suyu ve kırılmış cips parçacıkları bunlardan bazılarıdır. Patates kabuğu oldukça iyi bir karbonhidrat kaynağı olmasının yanı sıra patateste bulunan fenolik bileşenlerin çoğunluğunun kabukta olması nedeniyle de iyi bir fenolik kaynağıdır. Patateste bulunan fenolik bileşenler fenolik asitler (klorojenik asit, kafeik asit, ferulik asit, gallik asit, p-kumarik asit, sirinjik acid, vanilik acid, sinapik asit, salisilik asit) ve flavonoidlerdir (flavonols, flavanols, ve anthocyanins) (Akyol ve ark., 2016). Patates kabuğu aynı zamanda bazı enzimlerin (mannanase (Mona ve Ahwany, 2008), alpha-amylase (Ikram-Ul-Haq ve ark., 2012), $\alpha$-amylase, proteases ve polygalacturonate lyase (Mahmood ve ark., 1998) üretiminde substrat olarak da kullanılmıştır. Patates diyet lifi (\%50) açısından da oldukça zengindir (Sharma ve ark., 2016). Nişasta üretiminde kullanılan tatlı patates atıklarından ise nişasta ve su uzaklaştırıldıktan sonra pektin elde edildiği (Zhang ve ark., 2013) ve patates kabuğundan polyphenol oxidase enziminin ekstrakt edildiği (Niphadkar ve Rathod, 2015) bilgileri de literatürde mevcuttur.

Meyve ve sebze işleme endüstrisinde yaygın olan uygulamalar; kurutma, meyve suyu üretimi, reçel yapımı, dondurulmuş doğranmış meyve ve sebzeler, turşu, konserve, marmelat yapımı ve ezme üretimidir. $\mathrm{Bu}$ işlemler esnasında çeşitli katı ve sıvı atıklar açığa çıkmaktadır ve bunlar fermente olabilen şekerler (früktoz, glikoz ve sakkaroz), diyet lifi, antioksidanlar, pektin, elzem yağ asitleri ve vitaminler gibi beslenme açısından oldukça önem arz eden bileşenlerce zenginlerdir. Günümüzde meyve ve sebze işleme atıklarının doğrudan bazı ürünlerde (unlu mamüller, kek, kurabiye, kahvaltılık gevrekler vb.) kullanılmak suretiyle değerlendirilmesinin yanı sıra sözü edilen değerli bileşiklerin ekstrakt edilerek değerlendirildiği durumlarda söz konusudur. Örneğin narenciye suyu üretiminde sıkılan bütün bir meyvenin yaklaşık \%50'si yan ürün olarak açığa çıkmaktadır ve bu atıklarından pektin, limonin, aroma bileşeni, monosakkarid parçalanma ürünleri, ve selüloz üretimi Clark ve ark. (2013) tarafından patent altına alınmıştır. Limon işleme atığından da (posa, kabuk ve çekirdek) pektin üretimi üzerine bilgiler mevcuttur (Masmoudi ve ark., 2008). Elma posası elma suyu endüstrisinin önemli bir atığıdır ve bundan da pektin üretimi mümkündür (Wang ve ark., 2007). Elma kabuğundan ise polifenollerin ekstraksiyonu da diğer bir değerlendirme biçimidir (Schieber ve ark., 2001). Şarap üretimi esnasında da çok büyük miktarlarda üzüm posası atığı açığa çıkmaktadır. Bu atık özellikle fenolik asitler, antosiyaninler ve flavanoller olmak üzere yüksek konsantrasyonda biyo-aktif bileşenler içermektedir (Yu ve Ahmedna, 2013; Allison ve Simmons, 2018).

Zeytinyağı üretimi sırasında yan ürün olarak kara su ile kabuk ve çekirdekleri içeren zeytin posası açığa çıkmaktadır. Zeytin posası (pirina) kullanılan ekstraksiyon metoduna bağlı olarak hali hazırda bünyesinde \%8'e kadar yağ ihtiva etmektedir. Pirina; polifenoller, yağ asitleri, pigmentler, tokoferoller, fitosteroller, uçucu ve aroma bileşenleri gibi gida katkı maddesi veya nutrasotikler olarak kullanılabilecek bileşenler içermektedirler. Koçak Yanık (2017) mikrodalga destekli ekstraksiyon kullanarak yaş pirinadan yağ ekstraksiyonu gerçekleştirmiştir. Mulinacci ve ark. (2005) zeytin katı atıklarında (pirina) fenolik kompozisyonuna ilişkin detaylı bir çalışma yapmışlardır. Zeytin 
pirinasından birçok farklı teknik kulanıllarak özellikle fenolikçe zengin bileşenlere sahip ekstraktlar elde edilmiştir. Örneğin; Cea Pavez ve ark. (2019) basınçlı su, Goldsmith ve ark. (2018) ultrases yardımıyla zengin fenolik içerikli ekstraktlar elde etmişlerdir.

Et ve et ürünleri işleme tesisleri de gıda sanayisinin önemli kollarından birisidir. Bu işletmelerden farklı yan ürünler (kan, yağ, protein, kemik, deri vb.) açığa çıkmaktadır. Bu yan ürünlerin değerlendirilmesi veya bertaraf edilebilmesi ülkemizde ve Avrupa birliği ülkelerinde ciddi yasal uygulamalara tabidir. Hayvan Kanı kesimhanelerde açığa çıkan başlıca yan ürünlerden birisidir. Hayvan kanı albümin ve fibrinojen gibi kaliteli proteinlerce zengindir. Kolajen bu önemli yan ürünlerden bir diğeridir. Vidal ve ark. (2020) küçükbaş hayvan kesim atıklarından \%18 seviyesinde kolajen elde etmişlerdir. Elde edilen kolajen kaynağı kuzu olduğunda köpük oluşturma özelliğinin daha üstün olduğu belirlenmiştir. Koyundan elde edilen kolajenin ise viskozitesinin daha yüksek olduğunu tespit etmişlerdir. Santana ve ark. (2020) tavuk işleme atığı olan ayaklardan elde ettikleri jelatin kalitesini ticari jelatin ile karşılaştırmışlardır. Tavuk ayağından elde edilen jelatinin duyusal açıdan daha tercih edildiğini bulmuşlardır. Ayrıca elde edilen jelatinden hazırlanan film özelliklerinin de selofan ve lateks gibi ticari malzemelere benzediğini rapor etmişlerdir.

Balık, deniz hayvanları ve yumuşalçaların işlenmesi, imalatı ve saklanması esnasında da ciddi oranlarda atıklar veya yan ürünler (toplam ağırlığın yaklaşık \%25-30’u) açığa çıkmaktadır. Bu atıklar peptidler, proteinler, doğal pigmentler, kalojen, yă̆ asiti, kitin, kitosan ve kalsiyum gibi değerli bileşenlerce zengin atıklardır. Bunlar çeşitli metotlarla geri kazanılıp farklı alanlarda kullanılabilme potansiyeline sahip değerli bileşenlerdir. Mirzapour-Kouhdasht ve ark. (2019) mikrodalga destekli ekstraksiyon ile sazan balığı yan ürünlerinden kolloidal jelatin ekstraksiyonu gerçekleştirmişlerdir. Binsi ve ark. (2017) benzer bir şekilde balık jelatini ekstraksiyonunu mikrodalga destekli sistemle gerçekleştirmişlerdir. Ayrıca, deniz ürünleri atıklarından elde edilen yağlar çoklu doymamış yağ asitlerince zengindirler ve bu özelliğinden dolayı çok farklı kullanım alanları vardır. Bazı balıklar ve kabuklu deniz ürünleri carotenoid kaynağıdır ve bu bileşenin geri kazanımı ve çeşitli gıda uygulamalarında kullanımı mevcuttur. Deniz ürünleri atıklarında bulunan ve geri kazanımı mümkün olan bir diğer önemli bileşende kalsiyumdur. Kalsiyum kemiklerden ve kabuklulardan arda kalan atıklardan geri kazanılabilir. Balık atıkları aynı zamanda bazı enzimlerin de kaynağıdır ve bu enzimlerin ekstraksiyonu da mümkün olabilir.

Süt işleme ve süt ürünleri imalatı da gıda sanayisinin en büyük kollarından birisidir. Süt işlenmesi veya peynir, yoğurt, tereyağı gibi süt ürünleri imalatı esnasında da ciddi miktarlarda yan ürün veya atık açığa çıkmaktadır. Bunlardan en önemlisi peynir altı suyudur. Peynir altı suyu proteinlerce zengin, yüksek miktarda laktoz içeren ve gıda sanayinin başka kollarında dolaylı ya da direkt olarak kullanılan bir yan üründür. Bunun haricinde taze süt işlenmeden önce bazı safsızlıklardan arındırılmak için santrifüjden geçirilir ve bu işlemden sonra besin değeri oldukça yüksek bir tortu atık olarak açı̆ga çıkar. Bu tortu da farklı amaçlar için kullanılabilir.

\section{Mikrodalga Destekli Çözgen Ekstraksiyonunun Temel Prensipleri}

Mikrodalgalar frekansı 0,3 ile $300 \mathrm{GHz}$ arasında değişen elektromanyetik dalgalardır (Camel, 2001). Mikrodalga yayan cihazların iki ana uygulaması telekomünikasyon ve isıtmadır. Tüm ev tipi mikrodalga firınlar ve kimyasal sentez için özel mikrodalga reaktörler, telekomünikasyon ve radar frekansları ile etkileşimi önlemek için 2,45 GHz frekans kullanırlar (Gjuraj ve ark., 2012). Mikrodalga destekli çözgen ekstraksiyon sistemlerinde mikrodalga enerjisinin etkisi kullanılan çözücü ve matrisin dielektrik özelliklerine (absorblama, dielektrik sabiti ve kayıp faktörü) oldukça bağlıdır. "Relatif geçirgenlik" olarak da bilinen dielektrik sabiti $(\dot{\varepsilon})$, malzeme içerisinden geçen mikrodalga enerjisinin malzeme tarafından alıkonma yeteneğinin göstergesidir. Dielektrik kayıp faktörü $\left(\varepsilon^{\prime}\right)$ ise malzemeye gönderilen mikrodalga enerjisinin ne kadarının malzeme içinde 1sı olarak tüketilerek kayıp olduğunun göstergesidir. Mikrodalgaya maruz kalan malzemenin sabit bir frekans ve sıcaklıkta elektromanyetik enerjiyi 1sı enerjisine dönüştürme verimi ise kayıp tanjantı (tan $\delta$ ) ile ölçülür ve bu değer malzemenin dielektrik kaybının $\left(\varepsilon^{\circ)}\right)$ dielektrik sabitine $(\dot{\varepsilon})$ oranıdır, [tan $\delta=\left(\varepsilon^{\circ}\right) /(\dot{\varepsilon})$ ] (Samanlı ve ark., 2017). Dolayısıyla kayıp faktörü yüksek olan malzemeler mikrodalga enerjisi ile kolaylıkla 1sıtılabilirken kayıp faktörü çok düşük olan malzemeler mikrodalgayı absorblayıcı olmadıkları diğer bir deyişle transparan yapıda oldukları için bu malzemeler 1sınmazlar. Diğer taraftan metaller gibi elektriksel iletken malzemelerde mikrodalgaları yüzeyden geri yansıtır ve 1sınmazlar. Özetle su, şeker ve yağ gibi elektromanyetik alana maruz kaldıklarında mikrodalgayı soğuran malzemeler mikrodalga ile 1sıtılabilir. Çizelge 1'de MDÇE'da yaygın kullanılan bazı çözücülerin dielektrik özellikleri, kaynama noktaları ve kapalı kap maksimum sıcaklıkları verilmiştir. Örneğin polar olmayan hekzan ve tetrahidrofuran gibi dipol momenti düşük olan çözücüler mikrodalga radyasyonu altında 1sınmazken dipol momenti yüksek olan aseton ve su gibi çözücüler saniyeler içinde ısınacaklardır. Dolayısıyla MDÇE'da ekstraksiyonda

30 | P a g e 
seçiciliği sağlayabilmek ve/veya ortamın mikrodalga davranışını istenilen yönde değiştirebilmek için farklı çözücü karışımlarının kullanılması oldukça yaygındır. Örneğin, ortamın mikrodalga emme kapasitesini arttırmak için iyonik sıvılar veya alkoller gibi polar malzemelerin eklenmesi ya da SiC gibi kimyasal olarak etkisiz ve mikrodalga emiciliği yüksek olan pasif isitma malzemeleri ortama eklenebilir. MDÇE'da bir diğer önemli hususta matriksin su ihtivasıdır. Büyük dielektrik sabiti ve yüksek dipol momente sahip olan su bulunduğu yerde lokalize süper isıtma sağlayarak ekstrakt edilmek istenen bileşenin kolaylıkla çözücüye geçmesini sağlamaktadır. Dolayısıyla doğru ve tekrarlanabilir sonuçlar elde edilebilmesi için MDÇE'da matrisin su ihtivasının kontrol edilmesi elzemdir.

Çizelge 1. Mikrodalga destekli ekstraksiyonlarda kullanılan bazı çözücülerin dielektrik özellikleria, kaynama noktaları ve kapalı kap maksimum sıcaklıkları

\begin{tabular}{lccccc}
\hline & $\begin{array}{c}\text { Tan } \delta \\
\left(\mathrm{x} 10^{4}\right)\end{array}$ & $\dot{\varepsilon}$ & $\varepsilon^{\text {“ }}$ & $\begin{array}{c}\text { Kaynama } \\
\text { noktas } 1 \\
\left({ }^{\circ} \mathrm{C}\right)\end{array}$ & $\begin{array}{c}\text { Maksimum kapalı } \\
\text { sistem sicaklığ }\left({ }^{\circ} \mathrm{C}\right)\end{array}$ \\
\hline Aseton & 5555 & 21,1 & 11,5 & 56,2 & 164 \\
Asetonitril & 620 & 37,5 & 2,3 & 81,6 & 194 \\
Etanol & 2500 & 24,3 & 6,1 & 78,3 & 164 \\
Etil asetat & 5312 & 6,02 & 3,2 & 77 & Isinma yok \\
Hekzan & 0,10 & 1,89 & 0,00019 & 68,7 & 151 \\
Metanol & 6400 & 23,9 & 15,3 & 64,7 & Isinma yok \\
Tetrahidrofuran & & 7,58 & & 66 & \\
Su & 1570 & 76,7 & 12,0 & 100 & \\
\hline
\end{tabular}

${ }^{\mathrm{a}}$ Değerler $25^{\circ} \mathrm{C}$ ve $2450 \mathrm{MHz}$ te belirlenmiştir.

Dielektrik 1sıtma olarak da bilinen mikrodalga 1sıtmada $1 \mathrm{~s} 1$ üretim mekanizması malzemelerin mikrodalga ışınımını 1sıya dönüştürmesine dayanır. Mikrodalgalar bir birine dik olan elektrik ve manyetik alan yaratan elektromanyetik dalgalardır. Mikrodalgaya maruz birakılan malzemelerde mikrodalgaların soğurulması sonucunda ısınmanın temeli de bu elektrik alanın neden olduğu iyonların iletimi ve dipol rotasyonu (dönme) mekanizmalarına dayanır (Şekil 1) (Thuéry,1992; Demesmay ve Olle, 1993; Sinquin ve ark., 1993, Kaufmann ve Christen, 2002). Çoğu uygulamalarda bu iki mekanizma eş zamanlı meydana gelir. İyonik iletim, bir manyetik alan uygulandığında iyonların elektroforetik göçüdür. Bir değişken elektrik alanın etkisi altında salınım hareketine katılan çözünmüş yüklü parçacıklar, bitişik moleküller ile çarpışır ve böylece çözelti ısınır (Gjuraj ve ark., 2012). Dipol rotasyonu ise, uygulanan manyetik alanla dipollerin yeniden düzenlenmesi anlamına gelir. $2.45 \mathrm{GHz}$ frekansta bu olay saniyede 4.9x109 kez gerçekleşir ve bu moleküler dönme hareketine bağlı olarak ortaya çıkan sürtünme kuvveti sonucunda da hızlı bir isınma meydana gelir (Ganzler ve ark., 1990; Sinquin ve ark., 1993; Barnabas ve ark.., 1995; Kaufmann ve Christen, 2002).

$\mathrm{Bu}$ sayede mikrodalga destekli çözgen ekstraksiyonunda klasik kondüksiyon 1sınma sistemlerinden farklı olarak tüm sistem (çözelti ve örnek) eşzamanlı olarak ısınır (Şekil 1). Bazı durumlarda mikrodalga enerjisi uygulamaları ekstraksiyona non-termal (Isı ile ilişkisiz) bir katkıda sağlayabilmektedir. Lokalize isıtma örneklerde hücre duvarlarının genişleyip yırtılmasına neden olmakta ve bu sayede de ekstrakte edilebilir bileşenlerin kolaylıkla serbest kalıp çözücüye geçmesini sağlamaktadır (Paré ve ark., 1994; Jassie ve ark., 1997).

Mikrodalga teorisinde bir başka önemli noktada penetrasyon derinliğidir ve mikrodalga gücünün başlangıç değerinin \% 36,8'ine düştüğü noktayı temsil eden 1/e olarak bilinen standart değere göre hesaplanır. Penetrasyon derinliği malzemenin kayıp tanjantı ile ters orantılıdır dolayısıyla kayıp tanjantı yüksek olan malzemeler için mikrodalganın penetrasyon derinliği düşüktür. Bu tür malzemelerde mikrodalga dış katmanlarında emildiği için malzemenin iç kısmı daha sonra geleneksel konveksiyon mekanizması ile isınır. 


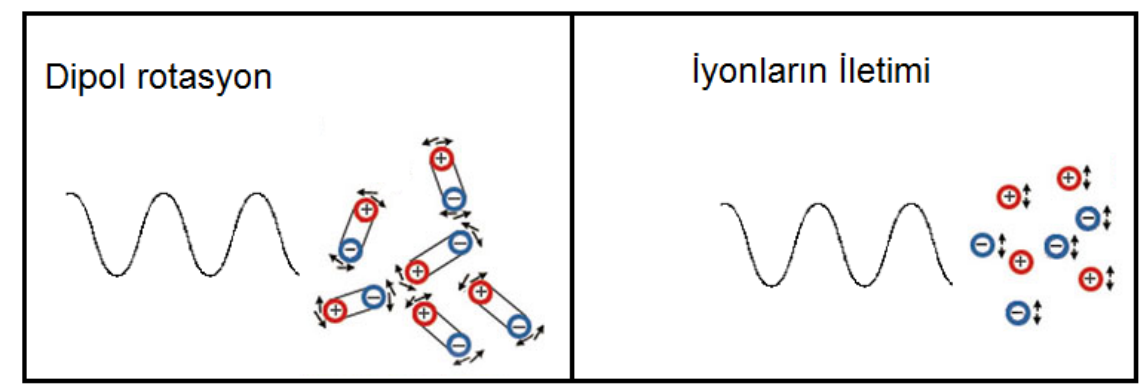

Şekil 1. Mikrodalga etkisiyle dipollerin rotasyonu ve iyon göçü mekanizmalarının gösterimi.

\section{Mikrodalga Uygulama Sistemleri}

Ticari olarak kullanılabilir iki çeşit mikrodalga sistemi mevcuttur. Bunlar tekli mod (odaklanmış sistem) ve çoklu mod mikrodalga sistemleridir (Şekil 2. a,b). Tekli mod mikrodalga cihazlarında tek bir numune mikrodalga enerjisinin büyüklüğünün en yüksek olduğu noktaya yerleştirilir ve üretilen mikrodalga bu noktaya yönlendirilir dolayısıyla tekli mod cihazlarının avantajı yüksek 1sıtma sağlamasıdır. Bu cihazların bir diğer önemli özelliği de reaksiyon sisteminin basıç̧lı hava veya sıvı azot kullanılarak soğutulabilmesidir. Fakat her seferinde sadece bir numune kabı için uygulama gerçekleştirilebilir olması bu sistemin en büyük dezavantajıdır. Bu cihazlar hacmi 0,2-50 ml olan kapalı kap koşulları $\left(250^{\circ} \mathrm{C}, 20\right.$ bar) ve150 ml ye kadar ki açık kap koşulları için uygundur (Kappe, 2004). Tekli mod mikrodalga ısıtma donanımları yaygın olarak küçük miktarlardaki ilaç sentezi, otomasyon ve kombinatoriyal kimya uygulamaları için kullanılmaktadır (Özdemir ve Akdeste, 2011).
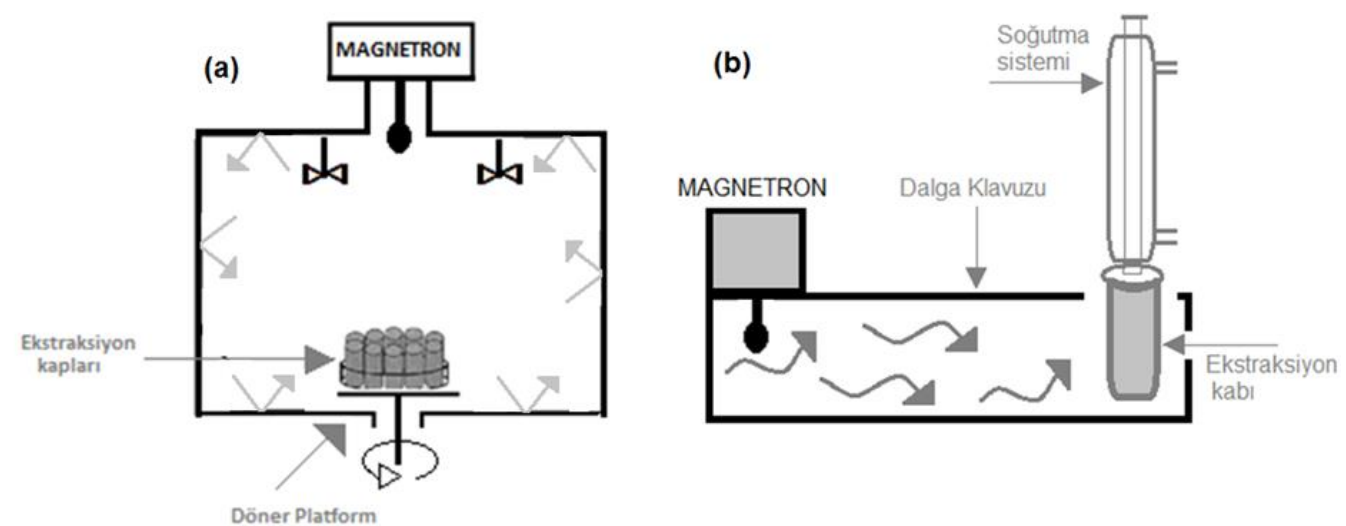

Şekil 2. Çoklu (a) ve tekli mod (b) mikrodalga sistemi şematik gösterimi.

Çoklu mod cihazların en temel farkı numuneye sabit bir dalga gönderilmemesidir. Bu sistemlerde amaç cihazın içinde olabildiğince mikrodalga radyasyonunu dağıtabilmektir. Mikrodalga radyasyonu ne kadar dağıtılabilirse o derece yayılır ve cihazda 1sıtma daha etkili gerçekleşir. Tekli mod mikrodalga cihazında sadece bir reaksiyon kabı bulunabilmesinin aksine çoklu mod mikrodalga cihazı, iç hacminin geniş olmasından dolayı çok sayıda reaksiyon kabını aynı anda bulundurabilir. Bu özellik sayesinde çoklu mod mikrodalga cihazı hacimli ısıtma ve kimyasal analiz yöntemleri için kullanılabilir. Çoklu mod cihazlarının birçoğunda, birkaç litrelik reaksiyon karışımlarının 1sıtılması sağlanabildiği gibi bu reaksiyonlar açık ya da kapalı kap koşullarından her hangi birisine de sahip olabilir. Son zamanlardaki gelişmelerle tekli ve çoklu mod cihazlarında kilolarca madde hazırlanmasına imkân sağlayacak koşulların geliştirilmesi noktasında önemli sonuçlar alınmıştır. Çoklu mod cihazının en önemli dezavantajı dağıtılan radyasyonla ısıtılan numunelerin verimli şekilde kontrol edilememesidir. $\mathrm{Bu}$ nedenle de art arda 1sıtılan benzer ya da aynı tip numuneler için eşit 1sıtılma koşulları sağlanmayabilir (Özdemir ve Akdeste, 2011).

$\mathrm{Bu}$ sistemlerde kapalı (basınç altında) kap ve açık (atmosferik basınç altında) kap kullanılarak uygulama yapılabilmektedir. Kontrol edilebilir basınç ve sıcaklık altında çalışan kapalı sistem MDÇE'da en çok tercih edilen sistemdir. Kapalı kap sisteminde basınç arttı̆̆ından dolayı kullanılan çözgenler atmosferik basınçtaki kaynama noktasından daha yüksek sıcaklıklara 1sıtılabilir. Kapalı sistemde kap içerisindeki basınç kullanılan çözücünün kaynama noktasına ve hacmine bağlı olarak 
değişecektir. Kapalı kap sistemlerde işlem bittikten sonra kabın ağzının açılmadan önce oda sıcaklığına kadar soğuması beklenir buda kapalı sistemlerin diğer bir dezavantajıdır. Kapalı kap sistemde verilebilecek maksimum güç yaklaşık olarak 600 ile $1000 \mathrm{~W}$ arasında değişebilmektedir (Destandau ve ark., 2013).

Açık kap sistemlerde işlem atmosfer koşullarda gerçekleşmektedir dolayısıyla sıcaklık çözgenin atmosferik basınçtaki kaynama noktasıyla sinırlıdır. Bu sistemde isınıp buharlaşan çözgen geri soğutucu vasitasıyla kondense olup tekrar numune kabına gönderilmektedir. $\mathrm{Bu}$ esnada haznesine yerleştirilmiş numune üzerine odaklanan mikrodalgalar hızlı ve homojen bir ısınma sağlamaktadır. Açık kap sistemler daha güvenli olmasının yanı sıra kapalı kap sistemlerin aksine bir defada büyük miktarlarda numunelerin ekstraksiyonuna da olanak tanımaktadır.

Ayrıca bilimsel çalı̧̧malarda kullanılmak üzere geliştirilen çeşitli modifiye mikrodalga ekstraksiyon sistemleri de mevcuttur. Örneğin 1sıya duyarlı bileşiklerin ekstraksiyonu için daha 1lımlı çalı̧̧ma koşullarının sağlandığı vakumlu mikrodalga destekli ekstraksiyon sistemi geliştirilmiştir. Bu sistemde aktif bileşiklerin maddeden çözücüye kütle transfer mekanizması emme basıncı sayesinde meydana gelir. Ekstraksiyon teknesini basınç altında tutmak ve ekstraksiyon sırasında oksijene duyarlı moleküllerin oksidasyonunu önlemek için nitrojenin kullanıldığı azot korumalı mikrodalga destekli ekstraksiyon sistemi bir diğer modifiye mikrodalga ekstraksiyon sistemidir. Kombine mikrodalga ve ultrasonik dalgaların kullanıldığı ve böylece kütle aktarım mekanizmasını yoğunlaştırdığı ultrasonik mikrodalga destekli ekstraksiyon sistemleri de geliştirilmiştir. Ekstraksiyon sürecinin sürekli ve otomatik bir şekilde uygulandığı ve lineer olmayan bir analitik adımla birleştirildiği dinamik mikrodalga destekli ekstraksiyon sistemleri de bir diğer örnektir (Llompart ve ark., 2019).

$\mathrm{Bu}$ güne kadar mikrodalga sistemlerinin endüstride kullanımını kısıtlayan en önemli faktör laboratuvar ölçekte kalması buna bağlı olarak da ancak miligramlar seviyesinde ürün elde edilebilmesiydi. Fakat günümüzde bu dezavantajı ortadan kaldıracak çok çeşitli proseslere ve saatte on binlerce litreye varan kapasitelere kolay entegre olabilen, çok yönlü mikrodalga destekli sürekli akış reaktörleri tasarlanmış ve ticari olarak üretilmektedir.

Mikrodalga isıtma, geleneksel ısıtma yöntemlerinden daha hızlı, daha verimli, daha temiz, daha yeşil ve daha güvenlidir. Özellikle ekstraksiyon amaçlı kullanılmak üzere tasarlanan sistemler; ekstrakt edilmesi planlanan bileşen konsantrasyonunun artırılması, çözgen ihtiyacının azaltılması ve kısa süre avantajları gibi üstünlüklere sahiptirler. Ancak yüksek yatırmm maliyeti ve ekstraksiyon sonrası katı fazın ayrışıırılması için bir filtrasyon işleminin gerekliliği gibi dezavantajları da bulunmaktadır. Tatke ve Jaiswal (2011) mikrodalga ekstraksiyon sisteminin avantajları ve elde edilen ekstraktların bitkisel ilaç araştırmalarında uygulanmaları üzerine detaylı bir derleme yapmışlardır.

\section{Mikrodalga-Destekli Solvent Ekstraksiyonunun Gıda İşleme Atıklarında Mevcut ve Potansiyel Uygulamaları}

Klasik ısıtma ile gerçekleştirilen termal reaksiyonların hemen hepsi mikrodalga enerjisi kullanarak da gerçekleştirilebilir. Klasik ssıtma sistemlerinin yerine mikrodalga enerjisinin kullanıldığı sistemlerde bahsedilen en önemli iki avantaj; kısa reaksiyon süreleri ve artan ürün verimidir. Bu avantajları göz önünde bulundurulduğunda, mikrodalga 1sıtma, gıda atıklarından önemli bileşenlerin geri kazanımı ve sentezlenmesi açısından da iyi bir metot olarak görülmüş ve bu konuda yapılan araştırmalarda son yıllarda artış olmuştur. Çizelge 2'de literatürde bulunan mikrodalga destekli ekstraksiyon uygulamalarında kullanılan sistemler, geri kazanımı hedeflenen bileşen, ekstraksiyon koşulları ve kullanılan çözgenler özetlenmişsir.

Çizelge 2. Mikrodalga destekli ekstraksiyon uygulamalarının literatür özeti

\begin{tabular}{lcccc}
\hline Hedef bileşen & Yan ürün & $\begin{array}{c}\text { Mikrodalga } \\
\text { Sistemi }\end{array}$ & $\begin{array}{c}\text { Ekstraksiyon koşulları } \\
\text { (Çözgen, numune } \\
\text { miktarı, güç, sıcaklık, } \\
\text { süre) }\end{array}$ & Referans \\
\hline Pektin & Elma küsbesi & Açık kap & $\begin{array}{c}\text { HCl solüsyonu; } 2 \text { g; 499,4 } \\
\text { W; 20,8 dk. }\end{array}$ & $\begin{array}{c}\text { Wang ve ark. } \\
(2007)\end{array}$ \\
\hline Fenolik bileşenler & Nar çekirdeği & $\begin{array}{c}\text { Ev tipi } \\
\text { mikrodalga firın }\end{array}$ & $\begin{array}{c}\text { Benzen ve hekzan; } 5 \text { g; } \\
\text { 200-800W; 30 sn. }\end{array}$ & $\begin{array}{c}\text { Abbasi ve ark. } \\
(2008)\end{array}$ \\
\hline Fenolik asitler & $\begin{array}{c}\text { Mandalina } \\
\text { kabuğu }\end{array}$ & Açık kap & $\begin{array}{c}\text { Metanol (\%66); } 5 \text { g; 152 } \\
\text { W; 49 sn. }\end{array}$ & $\begin{array}{c}\text { Hayat ve ark. } \\
(2009)\end{array}$ \\
\hline
\end{tabular}

33 | P a g e 


\begin{tabular}{|c|c|c|c|c|}
\hline Hedef bileşen & Yan ürün & $\begin{array}{l}\text { Mikrodalga } \\
\text { Sistemi }\end{array}$ & $\begin{array}{c}\text { Ekstraksiyon koşulları } \\
\text { (Çözgen, numune } \\
\text { miktarı, güç, sıcaklık, } \\
\text { süre) }\end{array}$ & Referans \\
\hline $\begin{array}{l}\text { Fenolik antioksidan } \\
\text { bileşikler }\end{array}$ & Findık zarı & Kapalı kap & $\begin{array}{c}\text { Etanol }(30 \%) ; 1,5 \mathrm{~g} ; 855 \\
\text { W; } 150 \mathrm{sn} .\end{array}$ & $\begin{array}{l}\text { Ballard ve ark. } \\
\text { (2010) }\end{array}$ \\
\hline Yağ & Pirina & $\begin{array}{c}\text { Modifiye } \\
\text { mikrodalga firın }\end{array}$ & Hekzan; $50 \mathrm{~g} ; 750 \mathrm{~W} ; 2 \mathrm{dk}$ & $\begin{array}{l}\text { Amarni ve Kadi } \\
(2010)\end{array}$ \\
\hline Polifenoller & Üzüm çekirdeği & Kapalı kap & $\begin{array}{l}\text { Etanol-su (\%10-90); 100- } \\
200 \mathrm{~W} ; 40-60{ }^{\circ} \mathrm{C} ; 2-32 \mathrm{dk}\end{array}$ & Li ve ark. (2011) \\
\hline Toplam polifenoller & Şarap tortusu & Kapalı kap & $\begin{array}{l}\text { Etanol }(\% 75) ; \mathrm{HCl}(\% 1) \\
2 \mathrm{~g} ; 200 \mathrm{~W} ; 17 \mathrm{dk}\end{array}$ & $\begin{array}{c}\text { Pérez-Serradilla } \\
\text { ve De Castro } \\
(2011)\end{array}$ \\
\hline Flavonoidler & Greyfurt kabuğu & Mikrodalga firın & $\begin{array}{c}\text { Etanol }(\% 80) ; 2 \mathrm{~g} ; 560 \mathrm{~W} \\
3 \mathrm{dk}\end{array}$ & $\begin{array}{l}\text { Wang ve ark. } \\
\qquad(2011)\end{array}$ \\
\hline Uçucu yağlar & Greyfurt kabuğu & Açık kap & $\begin{array}{c}\text { Çözgensiz; } 250 \text { g; 85W; } 20 \\
\text { dk. }\end{array}$ & $\begin{array}{l}\text { Uysal ve ark. } \\
\text { (2011) }\end{array}$ \\
\hline Pektin & Greyfurt kabuğu & Açık kap & $\begin{array}{c}\mathrm{Su}(\mathrm{pH} 1,5) ; 6 \mathrm{~g} ; 900 \mathrm{~W} ; 6 \\
\mathrm{dk} .\end{array}$ & $\begin{array}{c}\text { Bagherian ve ark. } \\
\text { (2011) }\end{array}$ \\
\hline Fenolik bileşenler & $\begin{array}{l}\text { Patates işleme } \\
\text { atıkları }\end{array}$ & Kapalı kap & $\begin{array}{l}\text { Etanol }(\% 60) ; 0,5 \mathrm{~g} \\
300 \mathrm{~W} ; 80^{\circ} \mathrm{C} ; 2 \mathrm{dk}\end{array}$ & Wu ve ark. (2012) \\
\hline Fenolik asit & $\begin{array}{l}\text { Mandalina } \\
\text { kabuğu }\end{array}$ & Kapalı kap & $\begin{array}{c}\mathrm{Su} ; 1 \mathrm{~g} ; 400 \mathrm{~W} ; 135^{\circ} \mathrm{C} ; 3 \\
\mathrm{dk} .\end{array}$ & $\begin{array}{c}\text { Ahmad ve } \\
\text { Langrish (2012) }\end{array}$ \\
\hline 2-furfural ve 5-HMF & Buğday samanı & Kapalı kap & $\begin{array}{c}\mathrm{H}_{2} \mathrm{O} / \mathrm{HCl} ; 140-190^{\circ} \mathrm{C} ; 1- \\
30 \mathrm{dk}\end{array}$ & $\begin{array}{l}\text { Yemiş ve Mazza } \\
\text { (2012) }\end{array}$ \\
\hline Pektin & $\begin{array}{l}\text { Şeker pancarı } \\
\text { küsbesi }\end{array}$ & Mikrodalga firın & $\begin{array}{l}\text { Sülfürik asit solüsyonu; } \\
\quad 152 \mathrm{~W} ; 3,53 \mathrm{dk} \text {. }\end{array}$ & Li ve ark. (2012) \\
\hline $\begin{array}{l}\text { Fermente olabilen } \\
\text { şekerler }\end{array}$ & $\begin{array}{l}\text { Pamuk bitkisi } \\
\text { atıkları }\end{array}$ & $\begin{array}{c}\text { Ev tipi } \\
\text { mikrodalga firın }\end{array}$ & Alkali su; $300 \mathrm{~W}, 6 \mathrm{dk}$. & $\begin{array}{l}\text { Vani ve ark. } \\
\text { (2012) }\end{array}$ \\
\hline Ferulik asit & $\begin{array}{l}\text { Biracılık yan } \\
\text { ürünü }\end{array}$ & Kapalı kap & $\begin{array}{c}\mathrm{H}_{2} \mathrm{O} / \mathrm{NaOH}(\% 0.5) ; 1 \mathrm{~g} ; \\
100{ }^{\circ} \mathrm{C} ; 15 \mathrm{~min}\end{array}$ & $\begin{array}{l}\text { Moreira ve ark. } \\
\quad(2012)\end{array}$ \\
\hline Jelatin & Kaz ayağ1 & $\begin{array}{c}\text { Ev tipi } \\
\text { mikrodalga firın }\end{array}$ & $350 \mathrm{~W}, 5 \mathrm{dk}$ & $\begin{array}{l}\text { Park ve ark. } \\
\text { (2013) }\end{array}$ \\
\hline D-limonen & Portakal kabuğu & Kapalı kap & $\begin{array}{l}\text { Hekzan; } 1 \mathrm{~g} ; 200 \mathrm{~W} ; 110 \\
{ }^{\circ} \mathrm{C} ; 30 \mathrm{dk} .\end{array}$ & $\begin{array}{l}\text { Attard ve ark. } \\
\quad(2014)\end{array}$ \\
\hline Toplam polifenoller & $\begin{array}{l}\text { Kırmız1 üzüm } \\
\text { posası }\end{array}$ & Kapalı kap & $\begin{array}{l}\text { Su veya su:etanol }(1: 1) ; 2 \\
\text { g; } 200 \mathrm{~W} ; 50{ }^{\circ} \mathrm{C} ; 60 \mathrm{dk} .\end{array}$ & $\begin{array}{l}\text { Drosou ve ark. } \\
\quad(2015)\end{array}$ \\
\hline $\begin{array}{l}\text { Polifenoller ve } \\
\text { flavonoidler }\end{array}$ & $\begin{array}{l}\text { Civanperçemi } \\
\text { çayı üretim tozu }\end{array}$ & $\begin{array}{c}\text { Ev tipi } \\
\text { mikrodalga firın }\end{array}$ & $\begin{array}{c}\text { Etanol-su; } 3 \mathrm{~g} ; 170 \mathrm{~W} ; 33 \\
\text { sn. }\end{array}$ & $\begin{array}{l}\text { Milutinović ve } \\
\text { ark. (2015) }\end{array}$ \\
\hline Likopen & $\begin{array}{l}\text { Domates } \\
\text { Kabuğu }\end{array}$ & Kapalı kap & $\begin{array}{l}\text { Etil asetat; } 1-2-4 \mathrm{~g} ; 400 \mathrm{~W} ; \\
1 \mathrm{dk}\end{array}$ & Ho ve ark. (2015) \\
\hline Pektin & Mango kabuğu & Açık kap & $\mathrm{Su} ; 413 \mathrm{~W} ; 134 \mathrm{sn}$. & $\begin{array}{l}\text { Maran ve ark. } \\
\quad(2015)\end{array}$ \\
\hline Pektin & Papaya kabuğu & $\begin{array}{c}\text { Ev tipi } \\
\text { mikrodalga firın }\end{array}$ & $\mathrm{Su} ; 512 \mathrm{~W} ; 140 \mathrm{sn}$. & $\begin{array}{c}\text { Maran ve Prakash } \\
(2015)\end{array}$ \\
\hline Pektin & $\begin{array}{l}\text { Ekşi portakal } \\
\text { kabuğu }\end{array}$ & Mikrodalga firın & $\begin{array}{c}\text { Sitrik asit solüsyonu; } 700 \\
\text { W; } 3 \mathrm{dk} .\end{array}$ & $\begin{array}{l}\text { Hosseini ve ark. } \\
\text { (2016) }\end{array}$ \\
\hline
\end{tabular}




\begin{tabular}{|c|c|c|c|c|}
\hline Hedef bileşen & Yan ürün & $\begin{array}{l}\text { Mikrodalga } \\
\text { Sistemi }\end{array}$ & $\begin{array}{l}\text { Ekstraksiyon koşulları } \\
\text { (Çözgen, numune } \\
\text { miktarı, güç, sıcaklık, } \\
\text { süre) }\end{array}$ & Referans \\
\hline Yağ & Pirina & Kapalı kap & $\begin{array}{c}\text { Hekzan; } 2,5 \mathrm{~g} ; 287 \mathrm{~W} ; 16 \\
\min \end{array}$ & $\begin{array}{l}\text { Koçak Yanık, } \\
2017\end{array}$ \\
\hline $\begin{array}{l}\text { Biyoaktif } \\
\text { karbondidratlar } \\
\text { (inozitol ve inulin) }\end{array}$ & $\begin{array}{c}\text { Enginar işleme } \\
\text { atığ1 }\end{array}$ & Kapalı kap & $\begin{array}{c}\mathrm{Su} ; 0.1 \mathrm{~g} ; 900 \mathrm{~W} ; 50{ }^{\circ} \mathrm{C} ; 3 \\
\mathrm{dk} .\end{array}$ & $\begin{array}{l}\text { Ruiz-Aceituno ve } \\
\text { ark. (2016) }\end{array}$ \\
\hline $\begin{array}{l}\text { Triterpenoik asitler } \\
\text { (Maslinik /oleanolik } \\
\text { asit) }\end{array}$ & Pirina & Aç1k kap & $\begin{array}{c}\text { Etanol:su }(9: 1 \mathrm{v} / \mathrm{v}) ; 40^{\circ} \mathrm{C} \\
\text { (MA için } 10 \mathrm{dk} ., \text { OA için } \\
2,93 \mathrm{dk} .)\end{array}$ & $\begin{array}{l}\text { Ozkan ve ark. } \\
\text { (2017) }\end{array}$ \\
\hline $\begin{array}{l}\text { Polar olmayan } \\
\text { bileşenler }\end{array}$ & $\begin{array}{c}\text { Fistık yumuşak } \\
\text { kabuğu }\end{array}$ & Kapalı kap & $\begin{array}{c}\text { Hekzan; 1,5 g; } 250 \mathrm{~W} ; 12,5 \\
\mathrm{dk} .\end{array}$ & $\begin{array}{l}\text { Özbek ve ark. } \\
(2018)\end{array}$ \\
\hline Fenolik bileşenler & Pirina & Kapalı kap & $\begin{array}{l}\text { Kolin klorit:sitrik asit } \\
(1: 2) ; 2 \mathrm{~g} ; 200 \mathrm{~W} ; 30 \mathrm{dk} .\end{array}$ & $\begin{array}{l}\text { Chanioti ve Tzia } \\
\text { (2018) }\end{array}$ \\
\hline Fenolik bileşenler & Pirina & Kapalı kap & $\begin{array}{c}\text { Etanol (\%20); } 700 \mathrm{~W} ; 10 \\
\mathrm{dk} .\end{array}$ & $\begin{array}{l}\text { Jurmanović ve } \\
\text { ark. (2019) }\end{array}$ \\
\hline Fenolik bileşikler & $\begin{array}{c}\text { Fistık yumuşak } \\
\text { kabuğu }\end{array}$ & Kapalı kap & $\begin{array}{c}\text { Etanol (\%56); } 1 \mathrm{~g} ; 140 \mathrm{~W}, \\
4,5 \mathrm{dk} .\end{array}$ & $\begin{array}{l}\text { Özbek ve ark. } \\
(2020)\end{array}$ \\
\hline
\end{tabular}

Mikrodalga destekli ekstraksiyon çeşitli gıda atıklarından fenolik bileşenlerin ekstraksiyonunda sıklıkla kullanılmıştır ve bu yöntemle çok kısa sürede klasik yöntemlerle karşılaştırılabilir ya da daha yüksek ekstraksiyon verimi ile bileşenlerin elde edildiği belirlenmiştir. Klasik ekstraksiyon sistemlerinde (örneğin sokslet ekstraksiyonu) ekstraksiyon 3-6 saat arasında tamamlanırken mikrodalga 1sitmada bu süre dakikalarla sınırlıdır. Li ve ark. (2011) tarafından gerçekleştirilen çalı̧mada üzüm çekirdeğinin polifenollerinin \% 90'ından fazlasının sadece birkaç dakika içinde mikrodalga sistemi ile ekstrakte edildiği vurgulanmıştır. Barbero ve ark. (2006) kırmızı biberden kapsaisinin ekstraksiyonunda, Liazid ve ark., (2011) ise üzüm kabuklarından antosiyaninlerin ekstraksiyonunda MDÇE'da daha kısa ekstraksiyon süresi ile daha kaliteli ekstreler elde etmiş̧lerdir. Mikrodalga uygulaması yağ içeriği yüksek bazı atıklardan yağın ekstraksiyonunda da denenmiştir. Koçak Yanık (2017) tarafindan gerçekleştirilen çalışmada pirinadan sokslet ekstraksiyonuna kıyasla daha kaliteli bir yağ yüksek verimle (\% 97) çok kısa sürede (16 dk.) elde edilmiştir. Keskin Çavdar ve ark. (2017) tarafindan gerçekleştirilen çalışmada ise nar çekirdeğinden yağın ekstrakte edilmesinde yüksek verim elde etmek için mikrodalganın öneminden bahsedilmiştir. Geleneksel olarak, pektin asidik çözelti içinde yaklaşık $90{ }^{\circ} \mathrm{C}$ 'de en az 1 saat boyunca ekstrakte edilirken Hosseini ve ark. (2016) tarafindan mikrodalga ekstraksiyonu ile ekşi portakal kabuğundan $3 \mathrm{dk}$ içerisinde uygun saflıkta ve düşük metoksilli pektin sınıfında bir pektin başarıyla ekstrakt edilmiştir. Wang ve ark. (2007) ise elma posasından $20 \mathrm{dk}$ içinde pektin ekstrakt etmişlerdir. Ho ve ark. (2015) mikrodalga isıtma ile domates kabuğundan likopen eldesi üzerine çalışmalar gerçekleş̧irmiştir ve konvansiyonel ekstraksiyon yüksek oranda cis-likopen verimi gösterirken MDÇE'nun trans ve toplam likopen verimini önemli ölçüde iyileştirdiğini ortaya koymuştur. Binod ve ark. (2012) şeker kamışı küspesinden fermente edilebilir şeker elde edilmesinde kısa süreli mikrodalga ön işlem uygulamasının verimi önemli ölçüde iyileştirdiğini ortaya koymuştur. Vani ve ark. (2012) pamuk bitkisi atıklarından mikrodalga destekli alkali işlem uygulamak suretiyle lignoselülozik bileşenlerin parçalanması ve mayalanabilir şekerlerin elde edilmesi üzerinde çalışmışlardır. Mikrodalga uygulamasında yüksek basınç uygulamasına kıyasla 5 kat daha düşük enerji ihtiyacı ile biyoethanol üretilebileceğini rapor etmişlerdir. Mikrodalga uygulaması ile farklı kaynaklar kullanılmak suretiyle lignosellülozik bileşenlerin ayrıştırılması, selüloz ve hemiselülozun hidrolizi ile farklı amaçlar için kullanılabilecek şekerlerin üretilmesi üzerine bazı çalışmalar yapılmıştır. $\mathrm{Bu}$ çalışmalarda hem selüloz ve hemiselüloz verimleri artırılmış hem de toksik yan ürünlerin azaltılması yönünde çalışmalar yapılmıştır (Singh ve ark., 2017; Zhu ve ark., 2015). Jurmanovic ve ark. (2019) pirina fenoliklerinin ekstraksiyonunda mikrodalga kullanmışlardır. Çözgen olarak etanol kullanılan bu çalışmada mikrodalganın çok kısa bir sürede fenoliklerin ekstraksiyonunu sağladığg rapor edilmiş̧ir. Chanioti ve Tzia (2018) farklı teknikler kullanarak pirinadan biyoaktif bileşiklerin ekstraksiyon verimini çalı̧̧ışlardır. Mikrodalga destekli ekstraksiyon işleminin fenolik bileşiklerin 
ekstraksiyonunda hem verim açısından hem de yeşil kimya kullanılması açısından önemli bir teknik olduğunu vurgulamışlardır. Park ve ark. (2013) kaz ayağından farklı teknikler kullanarak jelatin eldesi üzerinde yaptıkları çalışmada mikrodalga uygulama ile elde edilen jelatinin diğer metotlarla elde edilenlere kıyasla daha iyi kalite özelliklerine sahip olduğunu bulmuşlardır.

\section{Sonuc ve Öneriler}

Son yıllarda artan gıda üretimine paralel olarak, gıda endüstrisi atıkları da önemli ölçüde artış göstermiştir. $\mathrm{Bu}$ artış, çevre kirliliği ve bazı değerli bileşenlerin kaybı gibi sorunları da beraberinde getirmiştir. Çevresel ve ekonomik faktörler göz önünde bulundurulduğunda, bu atıkların değerlendirilmesi ile ilgili çalışmalar giderek artmakta ve bu atıklarda bulunan değerli bileşenlerin geri kazanılmasını sağlayacak yeni uygulamaların bulunması önem arz etmektedir. Bu bağlamda gıda atıklarından hedef bileşenlerin geri kazanılması için mikrodalga destekli ekstraksiyon, geleneksel yöntemlere iyi bir alternatiftir. Mikrodalga destekli ekstraksiyon yönteminin işlem süresini kısaltan, çözgen tüketimini azaltan, ektraksiyon verimini arttıran ve hedef bileşenlerin bozulmasını minimum düzeyde tutan bir teknik olduğu ortaya koyulmuştur. Gıda atıklarından değerli bileşenlerin geri kazanılmasında kullanılan mikrodalga destekli ekstraksiyon yönteminin daha etkili bir şekilde kullanımı yapılacak olan çalışmalarla mümkündür. Bu çalışmalar, hem endüstriyel ölçekli üretime geçiş için ışık tutacak hem de gıda sektörünün gelişmesine katkıda bulunacaktır.

\section{References}

Abbasi, H., Rezaei, K., Emamdjomeh, Z., Mousavi, S.M.E. (2008). Effect of various extraction conditions on the phenolic contents of pomegranate seed oil. European Journal of Lipid Science and Technology, 110(5), 435-440

Ahmad, J., Langrish, T.A.G. (2012). Optimisation of total phenolic acids extraction from mandarin peels using microwave energy: The importance of the Maillard reaction. Journal of Food Engineering, 109(1), 162-174

Akyol, H., Riciputi, Y., Capanoglu, E., Caboni, M.F., Verardo, V. (2016). Phenolic compounds in the potato and its byproducts: an overview. International Journal of Molecular Sciences, 17(6), 835

Allison, B. J., Simmons, C.W. (2018). Obtaining multiple coproducts from red grape pomace via anthocyanin extraction and biogas production. Journal of Agricultural and Food Chemistry, $66(30), 8045-8053$

Amarni, F., Kadi, H. (2010). Kinetics study of microwave-assisted solvent extraction of oil from olive cake using hexane: comparison with the conventional extraction. Innovative Food Science \& Emerging Technologies, 11(2), 322-327

Attard, T.M., Watterson, B., Budarin, V.L., Clark, J.H., Hunt, A.J. (2014). Microwave assisted extraction as an important technology for valorising orange waste. New Journal of Chemistry, $38(6), 2278-2283$

Atwell, W.A. (2001). Wheat flour. St. Paul, MN: American Association of Cereal Chemists, Eagan Press.

Bagherian, H., Ashtiani, F.Z., Fouladitajar, A., Mohtashamy, M. (2011). Comparisons between conventional, microwave-and ultrasound-assisted methods for extraction of pectin from grapefruit. Chemical Engineering and Processing: Process Intensification, 50(11-12), 12371243

Ballard, T.S., Mallikarjunan, P., Zhou, K., O'Keefe, S. (2010). Microwave-assisted extraction of phenolic antioxidant compounds from peanut skins. Food Chemistry, 120(4), 1185-1192 
Barbero, G.F., Palma, M., Barroso, C.G. (2006). Determination of capsaicinoids in peppers by microwave-assisted extraction-high-performance liquid chromatography with fluorescence detection. Analytica chimica acta, 578(2), 227-233

Barnabas, I.J., Dean, J.R., Fowlis, I.A., Owen, S.P. (1995). Extraction of polycyclic aromatic hydrocarbons from highly contaminated soils using microwave energy. Analyst, 120(7), 18971904

Binod, P., Satyanagalakshmi, K., Sindhu, R., Janu, K.U., Sukumaran, R.K., Pandey, A. (2012). Short duration microwave assisted pretreatment enhances the enzymatic saccharification and fermentable sugar yield from sugarcane bagasse. Renewable Energy, 37(1), 109-116

Binsi P.K., Nayak N., Sarkar P.C., Joshy C.G., Ninan G., Ravishankar C.N. (2017). Gelation and thermal characteristics of microwave extracted fish gelatin-natural gum composite gels. Journal of Food Science and Technology, 54 (2) 518-530

Camel, V. (2001). Recent extraction techniques for solid matrices-supercritical fluid extraction, pressurized fluid extraction and microwave-assisted extraction: their potential and pitfalls. Analyst, 126(7), 1182-1193

Cea Pavez, I., Lozano-Sánchez, J., Borrás-Linares, I., Nuñez, H., Robert, P., Segura-Carretero, A. (2019). Obtaining an Extract Rich in Phenolic Compounds from Olive Pomace by Pressurized Liquid Extraction. Molecules, 24(17), 3108

Chanioti, S., Tzia, C. (2018). Extraction of phenolic compounds from olive pomace by using natural deep eutectic solvents and innovative extraction techniques. Innovative Food Science \& Emerging Technologies, 48, 228-239

Clark, J.H., Pfaltzgraff, L.A., Budarin, V. L., De Bruyn, M. (2013). U.S. Patent Application No. $14 / 390,633$

Demesmay, C., Olle, M. (1993). Utilisation des micro-ondes dans les laboratoires d'analyse: Préparation d'échantillons. Spectra 2000 Analyse, 22(175), 27-32

Destandau, E., Michel, T., Elfakir, C. (2013). Microwave-assisted Extraction. Natural Product Extraction: Principles and Applications, RSC Publishing: Cambridge, UK, 113-156

Đilas, S., Čanadanović-Brunet, J., Ćetković, G. (2009). By-products of fruits processing as a source of phytochemicals. Chemical Industry and Chemical Engineering Quarterly, 15(4), 191-202

Drosou, C., Kyriakopoulou, K., Bimpilas, A., Tsimogiannis, D., Krokida, M. (2015). A comparative study on different extraction techniques to recover red grape pomace polyphenols from vinification byproducts. Industrial Crops and Products, 75, 141-149

Durante, M., Lenucci, M.S., Rescio, L., Mita, G., Caretto, S. (2012). Durum wheat by-products as natural sources of valuable nutrients. Phytochemistry Reviews, 11, 255-262

Food and Agriculture Organization (FAO) (2011). Global food losses and food waste-Extent, causes and prevention. Rome. [Online] Available: http://www.fao.org/3/a-i2697e.pdf (May 15, 2020)

Food and Agriculture Organization (FAO) (2019). The Global Economy of Pulses. Rome. [Online] Available: http://www.fao.org/3/i7108en/I7108EN.pdf (May 15, 2020)

Food and Agriculture Organization (FAO) (2020). Cereal Supply and Demand Brief. [Online] Available: http://www.fao.org/worldfoodsituation/csdb/en/ (May 15, 2020) 
Galanakis, C.M. (2012). Recovery of high added-value components from food wastes: conventional, emerging technologies and commercialized applications. Trends in Food Science and Technology, 26, 68-87

Ganzler, K., Szinai, I., Salgo, A. (1990). Effective sample preparation method for extracting biologically active compounds from different matrices by a microwave technique. Journal of Chromatography A, 520, 257-262

Gjuraj, E., Kongoli, R., Shore, G. (2012). Combination of flow reactors with microwave-assisted synthesis: smart engineering concept for steering synthetic chemistry on the "fast lane". Chemical and Biochemical Engineering Quarterly, 26(3), 285-307

Goldsmith, C.D., Vuong, Q.V., Stathopoulos, C.E., Roach, P.D., Scarlett, C.J. (2018). Ultrasound increases the aqueous extraction of phenolic compounds with high antioxidant activity from olive pomace. $L W T, 89,284-290$

Hayat, K., Hussain, S., Abbas, S., Farooq, U., Ding, B., Xia, S., Jia, C., Zhang, X., Xia, W. (2009). Optimized microwave-assisted extraction of phenolic acids from citrus mandarin peels and evaluation of antioxidant activity in vitro. Separation and Purification Technology, 70(1), 63-70

Ho, K.K.H.Y., Ferruzzi, M.G., Liceaga, A.M., San Martín-González, M.F. (2015). Microwaveassisted extraction of lycopene in tomato peels: Effect of extraction conditions on all-trans and cis-isomer yields. LWT-Food Science and Technology, 62(1), 160-168

Hosseini, S.S., Khodaiyan, F., Yarmand, M.S. (2016). Optimization of microwave assisted extraction of pectin from sour orange peel and its physicochemical properties. Carbohydrate Polymers, 140, 59-65

Ikram-Ul-Haq, H.U., Mahmood, Z., Javed, M.M. (2012). Solid state fermentation for the production of $\alpha$-amylase by Paenibacillus amylolyticus. Pakistan Journal of Botany, 44, 341-346

Jassie, L., Revesz, R., Kierstead, T., Hasty, E., Matz, S. (1997). Microwave-assisted solvent extraction. Microwave-Enhanced Chemistry. Fundamentals, Sample Preparation, and Applications, Kingston HMS, Haswell SJ. eds). American Chemical Society: Washington, DC, 569-609

Jurmanovic, S., Jug, M., Safner, T., Radic, K., Domijan, A.M., Pedisic, S., Simic, S., Jablan, J., Cepo, D.V. (2019). Utilization of olive pomace as a source of polyphenols: optimization of microwaveassisted extraction and characterization of spray-dried extract. Journal of Food \& Nutrution Research, 58, 51-62

Kappe, C.O. (2004). Controlled microwave heating in modern organic synthesis. Angewandte Chemie International Edition, 43(46), 6250-6284

Kaufmann, B., Christen, P. (2002). Recent extraction techniques for natural products: microwaveassisted extraction and pressurised solvent extraction. Phytochemical Analysis, 13(2), 105-113

Keskin Çavdar, H., Koçak Yanık, D., Gök, U., Göğüş, F. (2017). Optimisation of microwaveassisted extraction of pomegranate (Punica granatum L.) seed oil and evaluation of its physicochemical and bioactive properties. Food Technology and Biotechnology, 55(1), 86-94

Kılıç, G. (1999). Evaluation of durum clear flour. Yüksek Lisans Tezi. Gaziantep Üniversitesi, Fen Bilimleri Enstitüsü, Gıda Mühendisliği Anabilim Dalı, Gaziantep, Türkiye.

Koçak Yanık, D. (2017). Alternative to traditional olive pomace oil extraction systems: Microwaveassisted solvent extraction of oil from wet olive pomace. $L W T, 77,45-51$

38 | P a g e

www.iiste.org 
Li, D.Q., Jia, X., Wei, Z., Liu, Z.Y. (2012). Box-Behnken experimental design for investigation of microwave-assisted extracted sugar beet pulp pectin. Carbohydrate Polymers, 88(1), 342-346

Li, Y., Skouroumounis, G.K., Elsey, G.M., Taylor, D.K. (2011). Microwave-assistance provides very rapid and efficient extraction of grape seed polyphenols. Food Chemistry, 129(2), 570-576

Liazid, A., Guerrero, R.F., Cantos, E., Palma, M., Barroso, C.G. (2011). Microwave assisted extraction of anthocyanins from grape skins. Food chemistry, 124(3), 1238-1243

Llompart, M., Garcia-Jares, C., Celeiro, M., Dagnac,T. (2019). Microwave-Assisted extraction. Encyclopedia of Analytical Science (third ed.), Academic Press, 67-77

Mahmood, A.U., Greenman, J., Scragg, A.H. (1998). Orange and potato peel extracts: Analysis and use as Bacillus substrates for the production of extracellular enzymes in continuous culture. Enzyme and Microbial Technology, 22(2), 130-137

Maran, J. P., Prakash, K.A. (2015). Process variables influence on microwave assisted extraction of pectin from waste Carcia papaya L. peel. International Journal of biological Macromolecules, $73,202-206$

Maran, J.P., Swathi, K., Jeevitha, P., Jayalakshmi, J., Ashvini, G. (2015). Microwave-assisted extraction of pectic polysaccharide from waste mango peel. Carbohydrate Polymers, 123, 67-71

Masmoudi, M., Besbes, S., Chaabouni, M., Robert, C., Paquot, M., Blecker, C., Attia, H. (2008). Optimization of pectin extraction from lemon by-product with acidified date juice using response surface methodology. Carbohydrate Polymers, 74(2), 185-192

Milutinović, M., Radovanović, N., Ćorović, M., Šiler-Marinković, S., Rajilić-Stojanović, M., Dimitrijević-Branković, S. (2015). Optimisation of microwave-assisted extraction parameters for antioxidants from waste Achillea millefolium dust. Industrial Crops and Products, 77, 333341

Mirzapour-Kouhdasht, A., Sabzipour, F., Taghizadeh, M.S., Moosavi-Nasab, M. (2019). Physicochemical, rheological, and molecular characterization of colloidal gelatin produced from Common carp by-products using microwave and ultrasound-assisted extraction. Journal of Texture Studies, 50(5), 416-425

Mona, E.M.M., Amani, M.D.E.A. (2008). Production of $\beta$-mannanase by Bacillus amyloliequifaciens 10A1 cultured on potato peels. African Journal of Biotechnology, 7(8), $1123-1128$

Moreira, M.M., Morais, S., Barros, A.A., Delerue-Matos, C., Guido, L.F. (2012). A novel application of microwave-assisted extraction of polyphenols from brewer's spent grain with HPLC-DAD-MS analysis. Analytical and Bioanalytical Chemistry, 403(4), 1019-1029

Mulinacci, N., Innocenti, M., La Marca, G., Mercalli, E., Giaccherini, C., Romani, A., Erica, S., Vincieri, F. F. (2005). Solid olive residues: Insight into their phenolic composition. Journal of Agricultural and Food Chemistry, 53(23), 8963-8969

Mullen, A.M., Álvarez, C., Pojić, M., Hadnadev, T.D., Papageorgiou, M. (2015). Classification and target compounds. In Food waste recovery, Academic Press, (pp. 25-57)

Niphadkar, S.S., Rathod, V.K. (2015). Ultrasound-assisted three-phase partitioning of polyphenol oxidase from potato peel (Solanum tuberosum). Biotechnology Progress, 31(5), 1340-1347 
Ozkan, G., Karacabey, E., Arslan, N., Odabasi, N. (2017). Optimisation of microwave-assisted extraction of triterpenoic acids from olive mill waste using response surface methodology. Quality Assurance and Safety of Crops \& Foods, 9(2), 179-185

Özbek, H.N., Yanık, D.K., Fadıloğlu, S., Çavdar, H.K., Göğüş, F. (2018). Microwave-assisted extraction of non-polar compounds from pistachio hull and characterization of extracts. Grasas y Aceites, 69(3), 260

Özbek, H.N., Yanık, D.K., Fadıloğlu, S., Göğüş, F. (2020). Optimization of microwave-assisted extraction of bioactive compounds from pistachio (Pistacia vera L.) hull. Separation Science and Technology, 55(2), 289-299

Özdemir, Z.Ö., Akdeste Z. (2011). Development of polyelectrolyte based bioconjugates using with synthetic viral peptides. Sigma, 29, 65-89

Paré, J.J., Bélanger, J.M., Stafford, S.S. (1994). Microwave-assisted process (MAPTM): a new tool for the analytical laboratory. TrAC Trends in Analytical Chemistry, 13(4), 176-184

Park, J.H., Choe, J.H., Kim, H.W., Hwang, K.E., Song, D.H., Yeo, E.J., Kim, H.Y., Choi, Y.S., Lee, S.H., Kim, C.J. (2013). Effects of various extraction methods on quality characteristics of duck feet gelatin. Food Science of Animal Resources, 33(2), 162-169

Pérez-Serradilla, J.A., De Castro, M.L. (2011). Microwave-assisted extraction of phenolic compounds from wine lees and spray-drying of the extract. Food Chemistry, 124(4), 1652-1659

Ruiz-Aceituno, L., García-Sarrió, M.J., Alonso-Rodriguez, B., Ramos, L., Sanz, M.L. (2016). Extraction of bioactive carbohydrates from artichoke (Cynara scolymus L.) external bracts using microwave assisted extraction and pressurized liquid extraction. Food Chemistry, 196, 11561162

Samanlı, S., Özcan, Ö., Geveze, K. (2017). Mikrodalga Kurutmanın Kaolen Numunesinin Bilyalı Değirmendeki Özgül Kırılma Hızını Artırıcı Etkisi. Dokuz Eylül Üniversitesi Mühendislik Fakültesi Fen ve Mühendislik Dergisi, 19(55), 267-278

Santana, J.C., Gardim, R.B., Almeida, P.F., Borini, G.B., Quispe, A.P., Llanos, S.A., Heredia, J.A., Zamuner, S., Gamarra, F.M.C., Farias, T.M.B., Ho, L.L., Berssaneti, F.T. (2020). Valorization of Chicken Feet By-Product of the Poultry Industry: High Qualities of Gelatin and Biofilm from Extraction of Collagen. Polymers, 12(3), 529

Schieber, A., Stintzing, F. C., Carle, R. (2001). By-products of plant food processing as a source of functional compounds-recent developments. Trends in Food Science \& Technology, 12(11), 401413

Sharma, S.K., Bansal, S., Mangal, M., Dixit, A.K., Gupta, R.K., \& Mangal, A.K. (2016). Utilization of food processing by-products as dietary, functional, and novel fiber: a review. Critical Reviews in Food Science and Nutrition, 56(10), 1647-1661

Singh, R., Bhuyan, K., Banerjee, J., Muir, J., Arora, A. (2017). Hydrothermal and microwave assisted alkali pretreatment for fractionation of arecanut husk. Industrial Crops and Products, $102,65-74$

Sinquin, A., Görner, T., Dellacherie, E. (1993). L'utilisation des micro-ondes en chimie analytique. Analusis, 21(1), 1-10 
Tamaki, Y., Mazza, G. (2010). Measurements of structural carbohydrates, lignins, and microcomponents of straw and shives: effects of extractives, particle size and crop species. Industrial Crops and Products, 31, 534-541

Tatke P., Jaiswal Y. (2011). An Overview of Microwave Assisted Extraction and its Applications in Herbal Drug Research. Research Journal of Medicinal Plants, 5, 21-30

Thuéry, J. (1992). Microwaves: industrial, scientific, and medical applications. Artech House on Demand.

Uysal, B., Sozmen, F., Aktas, O., Oksal, B.S., Kose, E.O. (2011). Essential oil composition and antibacterial activity of the grapefruit (Citrus Paradisi. L) peel essential oils obtained by solvent-free microwave extraction: comparison with hydrodistillation. International Journal of Food Science \& Technology, 46(7), 1455-1461

Vani, S., Binod, P., Kuttiraja, M., Sindhu, R., Sandhya, S.V., Preeti, V.E., Sukumaran, R.K., Pandey, A. (2012). Energy requirement for alkali assisted microwave and high pressure reactor pretreatments of cotton plant residue and its hydrolysis for fermentable sugar production for biofuel application. Bioresource Technology, 112, 300-307

Vidal, A.R., Duarte, L.P., Schmidt, M.M., Cansian, R. L., Fernandes, I.A., de Oliveira Mello, R., Demiate, I.M. Dornelles, R.C.P. (2020). Extraction and characterization of collagen from sheep slaughter by-products. Waste Management, 102, 838-846

Wang, S., Chen, F., Wu, J., Wang, Z., Liao, X., Hu, X. (2007). Optimization of pectin extraction assisted by microwave from apple pomace using response surface methodology. Journal of Food Engineering, 78(2), 693-700

Wang, T., Johnson, L.A. (2001). Refining high-free fatty acid wheat germ oil. Journal of the American Oil Chemists' Society, 78(1), 71-76

Wang, Z., Shang, Q., Wang, W., Feng, X. (2011). Microwave-assisted extraction and liquid chromatography/mass spectrometry analysis of flavonoids from grapefruit peel. Journal of Food Process Engineering, 34(3), 844-859

Wu, T., Yan, J., Liu, R., Marcone, M.F., Aisa, H.A., Tsao, R. (2012). Optimization of microwaveassisted extraction of phenolics from potato and its downstream waste using orthogonal array design. Food Chemistry, 133(4), 1292-1298

Yağc1, S., Göğüş, F. (2009). Development of extruded snack from food by-roducts: a response surface analysis. Journal of Food Process Engineering, 32(4), 565-586

Yemiş, O., Mazza, G. (2012). Optimization of furfural and 5-hydroxymethylfurfural production from wheat straw by a microwave-assisted process. Bioresource Technology, 109, 215-223

Yu, J., Ahmedna, M. (2013). Functional components of grape pomace: Their composition, biological properties and potential applications. International Journal of Food Science \& Technology, 48(2), 221-237

Zhang, Y.Y., Mu, T.H., Zhang, M. (2013). Optimisation of acid extraction of pectin from sweet potato residues by response surface methodology and its antiproliferation effect on cancer cells. International Journal of Food science \& Technology, 48(4), 778-785

Zhu, Z.Y., Simister, R., Bird, S., McQueen-Mason, S.J., Gomez, L.D., Macquarrie, D.J. (2015). Microwave assisted acid and alkali pretreatment of Miscanthus biomass for biorefineries. Aims Bioengineering, 2(4), 449-468 